OPEN ACCESS

Edited by:

Laurent Misery,

Université de Bretagne

Occidentale, France

Reviewed by:

Mario Sergio Palma

São Paulo State University, Brazil

Mario Geller,

Academy of Medicine of Rio de

Janeiro, Brazil

*Correspondence:

Urban Cerpes

urban.cerpes@medunigraz.at

Franz J. Legat

franz.legat@medunigraz.at

Specialty section

This article was submitted to Skin Allergy,

a section of the journal

Frontiers in Allergy

Received: 19 June 2021

Accepted: 30 July 2021

Published: 20 August 2021

Citation:

Cerpes $U$, Repelnig M-L and Legat FJ (2021) Itch in Hymenoptera Sting

Reactions. Front. Allergy 2:727776.

doi: 10.3389/falgy.2021.727776

\section{Itch in Hymenoptera Sting Reactions}

\author{
Urban Cerpes*, Maria-Lisa Repelnig and Franz J. Legat* \\ Department of Dermatology and Venerology, Medical University of Graz, Graz, Austria
}

Insect stings and the resulting itch are a ubiquitous problem. Stings by members of the insect order Hymenoptera, which includes sawflies, wasps, bees and ants, and especially by bees and wasps are extremely common, with $56-94 \%$ of the population being stung at least once in their lifetime. The complex process of venom activity and inflammation causes local reactions with pain and pruritus, sometimes anaphylactic reactions and more seldomly, as in case of numerous stings, systemic intoxication. We reviewed the literature regarding itch experienced after Hymenoptera stings, but found no study that placed a specific focus on this topic. Hymenoptera venoms are composed of many biologically active substances, including peptide toxins and proteinaceous toxins. Peptide toxins from bee venom cause cell lysis and ion channel modulation in the peripheral and central nervous systems, while toxins from wasp venom induce mast cell degranulation and chemotaxis of polymorphonuclear leukocytes in the skin. The proteinaceous toxins cause a disruption of the cell membranes and necrotic cell death, degradation of hyaluronan (an extracellular matrix glycosaminoglycan), increased vascular permeability, hemolysis, as well as activated platelet aggregation. Mediators which could be directly involved in the venom-induced pruritus include histamine and tryptase released from mast cells, interleukin-4 and interleukin-13 from Th2 lymphocytes, as well as leukotriene C4. We postulate that a pruriceptive itch is induced due to the pharmacological properties of Hymenoptera venoms.

Keywords: insect sting, Hymenoptera venom, pathophysiology, itch, venom activity

\section{INTRODUCTION}

Hymenoptera are a large order in the class of insects, which include sawflies (Symphyta), bees (Apoidae), wasps (Vespidae) and ants (Myrmicidiae). Hymenoptera stings are very common, with $56-94 \%$ of the population being stung at least once in their lifetime (1). Their venoms are natural weapons used for defense and/or predation, containing a complex mix of bioactive molecules, proteinaceous compounds and peptides (2). The envenomation process causes local inflammatory reactions accompanied by pain and pruritus, and more seldomly systemic intoxication after numerous stings $(3,4)$. The majority of medical important stings are caused by social Hymenoptera. In the clinic, anaphylaxis is the most important consequence observed after Hymenoptera stings, which are the most common triggers for anaphylaxis in adulthood in Europe $(5,6)$. However, Hymenoptera venoms are of interest due to their potential to cause anaphylaxis and inflammation, but also because they contain highly active biological compounds and are of interest as anti-microbial, anti-tumoral and anti-inflammatory therapeutics (7-9). 
Pruritus is an important and highly frequent sensation, which is experienced by any human being from time to time. Pruritus causes the desire to scratch, which is believed to assist in the removal of irritants, and, in the case of insect stings, to remove the inserted stinger or the whole insect from the skin. In recent years, many advances have been made that have improved our understanding of the pathogenesis of pruritus. In many cases, interactions have been found between inflammatory mediators and the peripheral and central nervous systems $(10,11)$. Prurioceptic neurons are currently classified as either histaminesensitive or histamine-insensitive neurons. Histamine, a biogenic amine, is capable of causing local immune cell activation and chemotaxis as well as regulation (12-14). This amine induces itch by binding to histamine receptors (H1R and H4R subtypes) located on histamine-sensitive sensory neurons, which have cell bodies located in the dorsal root ganglia (15). Non-histaminergic itch can also be mediated via various pathways such as proteaseactivated receptors, mas-related $G$ protein-coupled receptors (MRGPR), or cytokine receptors $(16,17)$. Cytokine receptors involved in non-histaminergic itch can be activated by several cytokines such as IL-4, IL-13, IL-31, IL-33, as well as thymic stromal lymphopoietin (TSLP) (18-22). In both histaminergic and non-histaminergic pathways, the transduction of the itch signal involves the activation of ion channels known as transient receptor potential channels (TRP), which include the important TRPV (vanilloid) and TRPA (ankyrin) subfamilies (23, 24). The stimulus is transmitted mainly via C-type neurons and to a lesser extent through $\mathrm{A} \delta$-neurons to the dorsal root ganglia, and then on to the dorsal horn of the spinal cord. The itch signal is then transmitted by inter-neurons to nerve fibers; the signal then crosses to the contralateral side, ascends through the spinothalamic tract to the thalamus and continues on to various brain regions $(17,25)$.

We conducted a literature review with the online search engine PubMed, which provides access to ca. 32 million citations from the MEDLINE bibliographic database, life science journals and online books, to identify publications on itch experienced after Hymenoptera stings. No study that placed a primary focus on this topic was found. Based on our own experience conducting sting provocation trials with live bees and wasps as a therapy control as part of an ongoing venom immunotherapy program, patients initially complain of pain and report experiencing pruritus within 20-30 min after being stung.

\section{COMPONENTS OF HYMENOPTERA VENOMS}

In this section, we present some of the main components of Hymenoptera venoms which might be implicated in the pathophysiology of itch. Many other components are known, and an excellent summary of these is provided in the review by dos Santos-Pinto et al. (26). The venoms of the species of the respective families do not contain entirely homologous proteins and peptides and, in the case of ants, have been poorly studied.

\section{Bee Venom Components Melittin}

The main component of bee venom is melittin, which accounts for $40-60 \%$ of the dry venom weight. Melittin is a basic 26-amino-acid polypeptide (https://pubchem.ncbi.nlm.nih.gov/ compound/16133648) which has cytolytic properties, causes muscle contractions, triggers the release of histamine and disrupts surface tension. It is considered to be one of the main pain-causing agents in bee venom (27). Melittin causes activation of transient receptor potential channel vanilloid 1 (TRPV1), a non-selective cation channel on peripheral sensory neurons (28). This receptor is implicated in nociception and the sensation of itch and is stimulated by histamine (29), but can also be stimulated by other important itch-inducing cytokines such as IL-31 and IL-4 (19). The receptor can be activated by its ligands, which are produced through the cyclooxygenase (COXs), lipoxygenase (LOXs) and phospholipase 2 (PLA 2) pathways (27). Another way to induce pruritus by melittin could be via the release of serotonin due to pore formation and mast cell degranulation (27). Melittin also increases transcriptional regulation of voltage-gated sodium channels on neurons associated with itch $(17,30)$. In addition, this polypeptide also activates phospholipase A2 (31).

\section{Phospholipase A2}

Phospholipase A2 (PLA) is a $16-18 \mathrm{kDa}$ protein, which accounts for $\sim 12 \%$ of dry bee venom weight (32). It hydrolyses the sn2 ester bond of glycerophospholipids in biological membranes to release free fatty acids and lysophospholipids (33). It also displays neurotoxic properties by binding to the N-type PLA2 receptor on neurons (34). When injected into rodents' skin, it has been shown that it induces the IgE-independent release of mediators from mast cells, such as pruritogenic IL-4 (35). Furthermore, it can induce a Th2 type cell response as well as the release of IL-33 (36). In a mouse model study, IL-33 and its receptor ST2 were implicated in pruritus due to poison ivy contact (20). Human PLA2 is also involved in reactions to lipoxygenase metabolites in the intracellular cascade of nociceptive and histamine-dependent itch signaling (37).

\section{Hyaluronidase}

Hyaluronidase is a constituent of the venoms from many Hymenoptera species. It is a $45-\mathrm{kDa}$ protein that degrades hyaluronic acid, an abundant glycosaminoglycan present in the extracellular matrix (38). It has been shown to increase the absorption, penetration of venoms and consequently their activity (39), which might also enhance itch.

\section{Vespid Venom Components Mastoparans}

Mastoparans are the most abundant proteins in wasp venoms, consisting of 12-14 amino acids (40). These proteins can cause cell lysis and IgE-independent mast cell degranulation, triggering the release of proinflammatory pruritogenic substances such as histamine, tryptase, leukotriene C4 (LTC 4), IL-4, IL-31, and IL33 (26, 41, 42). Tryptase has been shown to activate proteaseactivated receptor 2 (PAR-2), which can cause itch flares in 
TABLE 1 | Components of Hymenoptera venoms with their potential mechanism(s) of itch induction.

\begin{tabular}{|c|c|c|c|}
\hline Family & $\begin{array}{l}\text { Venom } \\
\text { component }\end{array}$ & Pathophysiology & Potential mechanism(s) of itch induction \\
\hline Apoidea & Melittin & $\begin{array}{l}\text { Cytolytic properties, Release of histamine and } \\
\text { disruption of surface tension }\end{array}$ & $\begin{array}{l}\text { Activation of TRPV1 on sensory neurons, release of } \\
\text { serotonin due to pore formation }\end{array}$ \\
\hline Apoidea & PLA2 & $\begin{array}{l}\text { Neurotoxicity via binding N-Type PLA2 receptors on } \\
\text { neurons, hydrolysation of glycerophospholipids }\end{array}$ & $\begin{array}{l}\text { IgE independent degranulation of mast cells, induce } \\
\text { Th2 Type immune response, human PLA2 is involved } \\
\text { in the intracellular histamine dependent itch signaling }\end{array}$ \\
\hline $\begin{array}{l}\text { Apoidea, } \\
\text { Vespidae }\end{array}$ & Hyaluronidase & Degradation of hyaluronic acid & Increases the penetration and activity of the venom \\
\hline Vespidae & Mastoparans & Cell lysis and lgE-independent mast cell degranulation & $\begin{array}{l}\text { Release of pruritogens from mast cells: Histamine, } \\
\text { tryptase, LTC 4, IL-4, IL-31, and IL-33 }\end{array}$ \\
\hline Vespidae & PLA1 & $\begin{array}{l}\text { Disruption of phospholipids in the cell membrane and } \\
\text { the formation of pores, leading to cell lysis, hemolysis, } \\
\text { platelet aggregation }\end{array}$ & $\begin{array}{l}\text { Induction of Th2 driven response over the release of } \\
\text { PGE2 from mast cells }\end{array}$ \\
\hline Vespidae & $\begin{array}{l}\text { Kinin-related } \\
\text { peptides }\end{array}$ & $\begin{array}{l}\text { Induction of inflammation, increases blood flow and } \\
\text { vascular permeability }\end{array}$ & $\begin{array}{l}\text { Induction of neurogenic inflammation with the release } \\
\text { of CGRP and substance P }\end{array}$ \\
\hline Myrmicidiae & Solenopsins & $\begin{array}{l}\text { Inducing histamine production in mastocytes, } \\
\text { activating platelets and neutrophils, blocking the } \\
\text { neuromuscular junction, mast cell degranulation }\end{array}$ & $\begin{array}{l}\text { Histamine release, mast cell degranulation, inhibiting } \\
\text { neuronal nitric oxide synthase }\end{array}$ \\
\hline
\end{tabular}

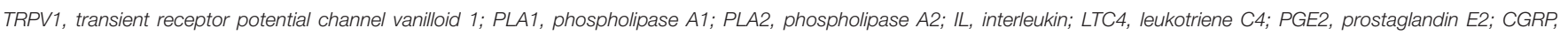
calcitonin gene-related peptide.

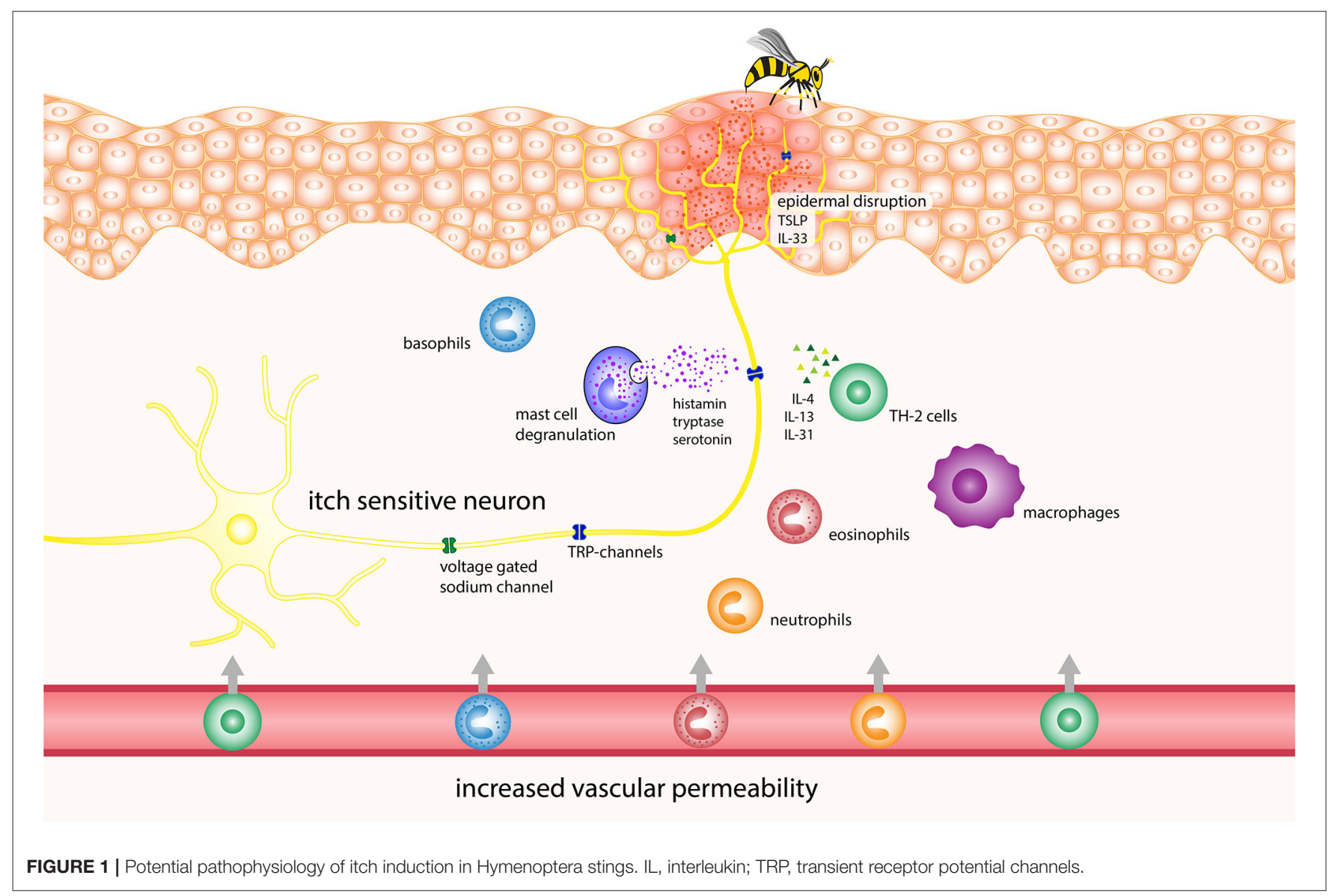

patients with atopic dermatitis. LTC 4 can mediate itch through the cysteinyl leukotriene receptor 2 (CysLTR2) on sensory nerves $(43,44)$.

\section{Phospholipase 1}

Phospholipase 1 (PLA1) is a non-glycosylated protein which is $\sim 20-30 \%$ homologous to the human lipase (45). It causes 
the disruption of phospholipids in the cell membrane and the formation of pores, leading to cell lysis, hemolysis and the activation of platelet aggregation (45-47). Researchers have demonstrated that PLA1 promotes the release of prostaglandin E2 (PGE2) from macrophages, which, in turn, induces Th2 inflammation with the release of Th2 type cytokines, such as the pruritogenic IL-4 (48).

\section{Kinin-Related Peptides}

Kinin-related peptides are polypeptides containing 9-18 amino acids, which are structurally similar to human pain-stimulating peptide bradykinin (49). Bradykinin plays an important role in inflammation in that it increases blood flow and vascular permeability. Via arachidonic acid metabolites and protein kinase $\mathrm{C}$, it also causes pain by activating TRPV1, which is also implicated in itch (50). Furthermore, bradykinin can stimulate neurosensory nerves by activating bradykinin B2-receptors, eventually inducing neurogenic inflammation with the release of CGRP (calcitonin gene-related peptide) and substance P, which again can directly and indirectly induce itch $(51,52)$. In addition, researchers reported that bradykinin causes itch when administered to human skin through iontophoresis (53).

\section{Ant Venom}

Due to lack of data on this topic, we do not focus on the specific proteins and components in ant venom but briefly review the known components.

\section{Ant Venom Alkaloids}

Venom alkaloids seem to be a unique feature of ants among Hymenopterans. Alkaloids in ants have been reported from an increasing number of different ant groups. Their structures are considerably diverse; however, alkaloids present in the venom from ants of the same species group tend to share the same basic structure. The chemistry and physiological effects of venom alkaloids have been most comprehensively studied in the fire ants. The alkaloids in fire ant venoms are mainly hydrophobic piperidines called solenopsins, while piperideines appear in much lower amounts. Solenopsins were shown to trigger histamine production in mastocytes, activating platelets and neutrophils, causing a blockade of the neuromuscular junction, inhibiting ATP-dependent sodium-potassium pumps and inhibiting neuronal nitric oxide synthase (54). While histamine release and mast cell degranulation are well-described mechanisms of itch, inhibiting neuronal nitric oxide synthase was shown to reduce itch in chloroquine-induced scratching (55). While platelet activation may lead to serotonin release and, therefore, induce itch, the study findings also indicate that the presence of neutrophils may lead to an upregulation of itch $(17,56)$.

\section{Ant Venom Proteins}

The exact immunological response to each venom component has not been empirically identified. However, a study exploring the allergic response mediated by fire ant venom proteins gives some insight into the physiological effects of ant venom proteins.
This study showed that the injection of ant venom proteins in previously sensitized mice led to an increase in eosinophils (57).

Eosinophils are a major cellular source of the highly pruritogenic cytokine IL-31 in bullous pemphigoid (58). Since ant venom proteins have shown to promote eosinophil recruitment, this may lead to an increased expression of IL-31 and, therefore, induce itch.

Ant venom protein exposure can also lead to dendritic cell activation and elevated IL-4 (57).

\section{Ant Venom Peptides}

To date at least 75 venom peptides from 11 ant species have been completely sequenced. These peptides can be grouped into three categories: cytolytic, neurotoxic and uncharacterized peptides. Most proteomic studies on ant venoms have shown the prevalence of small, linear peptides. Most of these small peptides possess cytolytic properties and also display hemolytic and insecticidal properties. Ponericins, dinoponeratoxins, pilosulins, and bicarinalins are included in this group of cytolytic peptides. It is believed that the cytolytic peptides identified in ant venoms are multifunctional; they act as membrane-disrupting agents, facilitate the diffusion of other neurotoxins and exhibit antimicrobial activity.

The neurotoxic properties of ant venom peptides have rarely been reported, and only a few neurotoxic peptides have been characterized (54). Poneratoxin modulates voltage-gated sodium (Nav) channels, which are also associated with itch (17). Ectatomin and poneritoxin are L-type voltage-gated calcium channel blockers, and ectatomin is additionally a pore-forming peptide (26). The pore forming process may lead to serotonin release, which can also be an inductor of itch. The complete sequence, structure and biological functions are still unknown for uncharacterized peptides, such as myrmexins and ICK-like peptides (26).

\section{POTENTIAL MECHANISMS FOR ITCH FROM HYMENOPTERA STINGS}

Since Hymenoptera venoms contain an abundant array of bioactive components, the separate examination of each of these would represent an overly simplistic und inadequate approach. Thus, in the next section, we discuss possible pathophysiological mechanisms of itch due to the epidermal disruption and the venom, placing a focus on immune system interplay. Table 1 lists the Hymenoptera venom components, with potential of itch induction and Figure 1 displays the potential pathophysiology of itch induction in Hymenoptera stings.

\section{Epidermal Disruption}

The initial stimulus for pruritus after Hymenoptera stings is believed to be due to damage caused to the epidermal barrier by the sting. This damage activates the immune cells, triggers the degranulation of mast cells and attracts circulating leukocytes $(59,60)$, resulting in the eventual release of TSLP, prostaglandin, histamine, serotonin, endothelin, nerve growth factor, as well as cytokines and chemokines (61). TSLP can trigger itch via direct neuronal activation as well as by initiating a Th2-type 
inflammation process, which involves the release of pruritogenic IL-4 and IL-13 $(62,63)$. Although these cytokines are primarily associated with chronic itch, they can also activate sensory neurons and increase their responsiveness to other itch mediators (19). Furthermore, the venom itself contains biogenic amines such as histamine and serotonin. Studies have shown that the latter can cause itch in humans and scratching in mice when injected into the skin $(64,65)$.

\section{Immune Response to Venom}

The immune response to venoms is mediated through mast cells, cell lysis and proinflammatory venom components, as described earlier. In addition, researchers have shown in animal models that honey bee venom attracts neutrophils and causes the rapid release of IL-1b, TNF- $\alpha$ and especially IL-6, as well as tachykinins such as substance $\mathrm{P}$ and neurokinin A $(66,67)$. Tachykinins released from sensory nerve fibers promote inflammation and cause edema via the neurokinin (NK)-1, NK-2 and NK-3 receptors. NK-1 receptors are found on mast cells, as well as other cells, where their activation can cause mast cell degranulation $(51,68)$. Furthermore, TNF- $\alpha$ has been implicated in acute itch in mice by sensitizing afferent neurons to other pruritogens (69). Higher serum levels of IL-6 have also been shown to correlate with higher itch levels in patients with prurigo nodularis (70), although the exact mechanism of IL-6-induced itch is not known.

\section{IgE-Mediated Itch}

Asymptomatic IgE-sensitization to Hymenoptera venoms is common, with $27.1-40.7 \%$ of the general population having detectable levels of specific IgE against them, although systemic sting reactions rarely occur in these people (71-73). Due to this fact, itch could be elicited via IgE-crosslinking of FceRI receptors mediating mast cell degranulation and the eventual release of pruritogenic mediators that were mentioned previously in the section describing mastoparans (42). Another way that $\operatorname{IgE}$ might cause itch is via the basophil-neuronal

\section{REFERENCES}

1. Antonicelli L, Bilo MB, Bonifazi F. Epidemiology of hymenoptera allergy. Curr Opin Allergy Clin Immunol. (2002) 2:3416. doi: 10.1097/00130832-200208000-00008

2. Muller UR. Hymenoptera venom proteins and peptides for diagnosis and treatment of venom allergic patients. Inflamm Allergy Drug Targets. (2011) 10:420-8. doi: $10.2174 / 187152811797200704$

3. Vetter RS, Visscher PK, Camazine S. Mass envenomations by honey bees and wasps. West J Med. (1999) 170:223-7.

4. Fitzgerald KT, Flood AA. Hymenoptera stings. Clin Tech Small Anim Pract. (2006) 21:194-204. doi: 10.1053/j.ctsap.2006.10.002

5. Worm M, Moneret-Vautrin A, Scherer K, Lang R, Fernandez-Rivas M, Cardona V, et al. First European data from the network of severe allergic reactions (NORA). Allergy. (2014) 69:1397-404. doi: 10.1111/all. 12475

6. Golden DB. Insect sting anaphylaxis. Immunol Allergy Clin North Am. (2007) 27:261-72, vii. doi: $10.1016 /$ j.iac.2007.03.008 axis, which has been implicated in itch during flare-ups of acute atopic dermatitis. When allergen-IgE binds to basophils, it causes the release of LTC4; this substance then binds to the LTC4 receptor CysLTR2 on afferent sensory neurons and causes pruritus via the activation of either TRPV1 or TRPA1 (74).

\section{CONCLUSIONS}

Hymenoptera venoms contain a diversity of biochemical substances and have complex biochemical properties. Due to the absence of comprehensive studies on the pruritic activity of Hymenoptera venoms, we can only speculate on the mechanisms of itch experienced after Hymenoptera stings. We suggest that the pruritus observed after Hymenoptera stings is induced by a combination of the epidermal disruption caused by the sting, the direct effects of the venom on afferent sensory neurons and pruritogenic, Th2-driven immune responses. Cells that play key roles in the skin during these processes include the mast cells, basophils, Th2 lymphocytes and keratinocytes. These cells release a wide range of bioactive compounds in response, such as histamine, serotonin, IL-4, IL-13, IL-31, and LTC4. All of these have been implicated in the direct or indirect induction of itch and mainly depend on the activity of TRPV1 and TRPA1 channels in the peripheral sensory neurons. The insufficient knowledge about the pathophysiology of pruritus after Hymenoptera stings highlights the necessity to conduct further studies on this topic, to address this knowledge gap and collect further evidence on this commonlyoccurring event.

\section{AUTHOR CONTRIBUTIONS}

UC, M-LR, and FJL reviewed literature, interpreted the data, and authored and revised the manuscript. UC and M-LR were the main authors of the manuscript. FJL supervised and critically discussed the manuscript with the other authors. All gave their final approval.

7. Tonk M, Vilcinskas A, Rahnamaeian M. Insect antimicrobial peptides: potential tools for the prevention of skin cancer. Appl Microbiol Biotechnol. (2016) 100:7397-405. doi: 10.1007/s00253-016-7718-y

8. Leite NB, Aufderhorst-Roberts A, Palma MS, Connell SD, Ruggiero Neto J, Beales PA. PE and PS lipids synergistically enhance membrane poration by a peptide with anticancer properties. Biophys J. (2015) 109:93647. doi: 10.1016/j.bpj.2015.07.033

9. Lee $\mathrm{G}, \mathrm{Bae} \mathrm{H}$. Anti-inflammatory applications of melittin, a major component of bee venom: detailed mechanism of action and adverse effects. Molecules. (2016) 21:616. doi: 10.3390/molecules21050616

10. Mu D, Deng J, Liu K-F, Wu Z-Y, Shi Y-F, Guo W-M, et al. A central neural circuit for itch sensation. Science. (2017) 357:695-9. doi: 10.1126/science.aaf4918

11. Han L, Ma C, Liu Q, Weng H-J, Cui Y, Tang Z, et al. A subpopulation of nociceptors specifically linked to itch. Nat Neurosci. (2013) 16:17482. doi: 10.1038/nn.3289

12. Thurmond RL, Desai PJ, Dunford PJ, Fung-Leung W-P, Hofstra CL, Jiang $\mathrm{W}$, et al. A potent and selective histamine $\mathrm{H}<4>$ receptor antagonist 
with anti-inflammatory properties. J Pharmacol Exp Therap. (2004) 309:404. doi: 10.1124/jpet.103.061754

13. László V, Rothe G, Hegyesi H, Szeberényi JB, Orsoó E, Schmitz $\mathrm{G}$, et al. Increased histidine decarboxylase expression during in vitro monocyte maturation; a possible role of endogenously synthesised histamine in monocyte/macrophage differentiation. Inflam Res. (2001) 50:42834. doi: $10.1007 /$ PL00000266

14. Simone DA, Ngeow JY, Whitehouse J, Becerra-Cabal L, Putterman GJ, LaMotte RH. The magnitude and duration of itch produced by intracutaneous injections of histamine. Somatosens Res. (1987) 5:8192. doi: $10.3109 / 07367228709144620$

15. Usoskin D, Furlan A, Islam S, Abdo H, Lönnerberg P, Lou D, et al. Unbiased classification of sensory neuron types by large-scale single-cell RNA sequencing. Nat Neurosci. (2015) 18:145-53. doi: 10.1038/nn.3881

16. Reddy VB, Azimi E, Chu L, Lerner EA. Mas-related G-protein coupled receptors and cowhage-induced itch. J Investig Dermatol. (2018) 138:4614. doi: 10.1016/j.jid.2017.05.042

17. Cevikbas F, Lerner EA. Physiology and pathophysiology of itch. Physiol Rev. (2020) 100:945-82. doi: 10.1152/physrev.00017.2019

18. Dillon SR, Sprecher C, Hammond A, Bilsborough J, RosenfeldFranklin M, Presnell SR, et al. Interleukin 31, a cytokine produced by activated $\mathrm{T}$ cells, induces dermatitis in mice. Nat Immunol. (2004) 5:752-60. doi: 10.1038/ni1084

19. Oetjen LK, Mack MR, Feng J, Whelan TM, Niu H, Guo CJ, et al. Sensory neurons co-opt classical immune signaling pathways to mediate chronic itch. Cell. (2017) 171:217-28.e13. doi: 10.1016/j.cell.2017.08.006

20. Liu B, Tai Y, Achanta S, Kaelberer MM, Caceres AI, Shao X, et al. IL-33/ST2 signaling excites sensory neurons and mediates itch response in a mouse model of poison ivy contact allergy. Proc Natl Acad Sci. (2016) 113:E75729. doi: 10.1073/pnas.1606608113

21. Zdeblick TA, Cooke ME, Wilson D, Kunz DN, McCabe R. Anterior cervical discectomy, fusion, and plating. A comparative animal study. Spine. (1993) 18:1974-83. doi: 10.1097/00007632-199310001-00009

22. Wilson Sarah R, Thé L, Batia Lyn M, Beattie K, Katibah George E, McClain Shannan P, et al. The epithelial cell-derived atopic dermatitis cytokine TSLP activates neurons to induce itch. Cell. (2013) 155:28595. doi: 10.1016/j.cell.2013.08.057

23. Dong X, Dong X. Peripheral and central mechanisms of itch. Neuron. (2018) 98:482-94. doi: 10.1016/j.neuron.2018.03.023

24. Sun S, Dong X. Trp channels and itch. Semin Immunopathol. (2016) 38:293307. doi: 10.1007/s00281-015-0530-4

25. Ringkamp M, Schepers RJ, Shimada SG, Johanek LM, Hartke TV, Borzan J, et al. A role for nociceptive, myelinated nerve fibers in itch sensation. $J$ Neurosci. (2011) 31:14841-9. doi: 10.1523/JNEUROSCI.3005-11.2011

26. dos Santos-Pinto JRA, Perez-Riverol A, Lasa AM, Palma MS. Diversity of peptidic and proteinaceous toxins from social Hymenoptera venoms. Toxicon. (2018) 148:172-96. doi: 10.1016/j.toxicon.2018.04.029

27. Chen J, Guan S-M, Sun W, Fu H. Melittin, the major painproducing substance of bee venom. Neurosci Bull. (2016) 32:265-72. doi: 10.1007/s12264-016-0024-y

28. Chen YN, Li KC, Li Z, Shang GW, Liu DN, Lu ZM, et al. Effects of bee venom peptidergic components on rat pain-related behaviors and inflammation. Neuroscience. (2006) 138:631-40. doi: 10.1016/j.neuroscience.2005.11.022

29. Tsagareli MG, Nozadze I, Tsiklauri N, Carstens MI, Gurtskaia G, Carstens E. Thermal hyperalgesia and mechanical allodynia elicited by histamine and non-histaminergic itch mediators: respective involvement of TRPV1 and TRPA1. Neuroscience. (2020) 449:35-45. doi: 10.1016/j.neuroscience.2020.09.048

30. Yu YQ, Zhao ZY, Chen XF, Xie F, Yang Y, Chen J. Activation of tetrodotoxin-resistant sodium channel NaV1.9 in rat primary sensory neurons contributes to melittin-induced pain behavior. Neuromol Med. (2013) 15:20917. doi: 10.1007/s12017-012-8211-0

31. Mollay C, Kreil G. Enhancement of bee venom phospholipase A2 activity by melittin, direct lytic factor from cobra venom and polymyxin B. FEBS Lett. (1974) 46:141-4. doi: 10.1016/0014-5793(74)80354-6

32. Jakob T, Müller U, Helbling A, Spillner E. Component resolved diagnostics for hymenoptera venom allergy. Curr Opin Allergy Clin Immunol. (2017) 17:363-72. doi: 10.1097/ACI.0000000000000390
33. Perez-Riverol A, Lasa AM, Dos Santos-Pinto JRA, Palma MS. Insect venom phospholipases A1 and A2: roles in the envenoming process and allergy. Insect Biochem Mol Biol. (2019) 105:10-24. doi: 10.1016/j.ibmb.2018.12.011

34. Nicolas JP, Lin Y, Lambeau G, Ghomashchi F, Lazdunski M, Gelb MH. Localization of structural elements of bee venom phospholipase A2 involved in N-type receptor binding and neurotoxicity. J Biol Chem. (1997) 272:717381. doi: $10.1074 /$ jbc. 272.11 .7173

35. Dudler T, Machado DC, Kolbe L, Annand RR, Rhodes N, Gelb MH, et al. A link between catalytic activity, IgE-independent mast cell activation, and allergenicity of bee venom phospholipase A2. J Immunol. (1995) 155:2605-13.

36. Palm NW, Rosenstein RK, Yu S, Schenten DD, Florsheim E, Medzhitov R. Bee venom phospholipase A2 induces a primary type 2 response that is dependent on the receptor ST2 and confers protective immunity. Immunity. (2013) 39:976-85. doi: 10.1016/j.immuni.2013.10.006

37. Imamachi N, Park GH, Lee H, Anderson DJ, Simon MI, Basbaum AI, et al. TRPV1-expressing primary afferents generate behavioral responses to pruritogens via multiple mechanisms. Proc Natl Acad Sci. (2009) 106:113305. doi: 10.1073/pnas.0905605106

38. Marković-Housley Z, Miglierini G, Soldatova L, Rizkallah PJ, Müller U, Schirmer T. Crystal structure of hyaluronidase, a major allergen of bee venom. Structure. (2000) 8:1025-35. doi: 10.1016/S0969-2126(00)00511-6

39. Ferrer VP, de Mari TL, Gremski LH, Trevisan Silva D, da Silveira RB, Gremski W, et al. A novel hyaluronidase from brown spider (Loxosceles intermedia) venom (Dietrich's Hyaluronidase): from cloning to functional characterization. PLoS Negl Trop Dis. (2013) 7:e2206. doi: 10.1371/journal.pntd.0002206

40. Lee SH, Baek JH, Yoon KA. Differential properties of venom peptides and proteins in solitary vs. social hunting wasps. Toxins. (2016) 8:32. doi: $10.3390 /$ toxins 8020032

41. dos Santos Cabrera MP, Costa ST, de Souza BM, Palma MS, Ruggiero JR, Ruggiero Neto J. Selectivity in the mechanism of action of antimicrobial mastoparan peptide Polybia-MP1. Eur Biophys J. (2008) 37:879-91. doi: 10.1007/s00249-008-0299-7

42. Elieh Ali Komi D, Wöhrl S, Bielory L. Mast cell biology at molecular level: a comprehensive review. Clin Rev Allergy Immunol. (2020) 58:34265. doi: 10.1007/s12016-019-08769-2

43. Lee SE, Jeong SK, Lee SH. Protease and protease-activated receptor-2 signaling in the pathogenesis of atopic dermatitis. Yonsei Med J. (2010) 51:80822. doi: $10.3349 / \mathrm{ymj} .2010 .51 .6 .808$

44. Voisin T, Perner C, Messou MA, Shiers S, Ualiyeva S, Kanaoka Y, et al. The CysLTR receptor mediates leukotriene C-driven acute and chronic itch. Proc Natl Acad Sci USA. (2021) 118:e2022087118. doi: 10.1073/pnas.2022087118

45. Hou MH, Chuang CY, Ko TP, Hu NJ, Chou CC, Shih YP, et al. Crystal structure of vespid phospholipase A reveals insights into the mechanism for cause of membrane dysfunction. Insect Biochem Mol Biol. (2016) 68:7988. doi: 10.1016/j.ibmb.2015.11.002

46. Santos LD, Santos KS, de Souza BM, Arcuri HA, Cunha-Neto E, Castro FM, et al. Purification, sequencing and structural characterization of the phospholipase $\mathrm{Al}$ from the venom of the social wasp Polybia paulista (Hymenoptera, Vespidae). Toxicon. (2007) 50:923-37. doi: 10.1016/j.toxicon.2007.06.027

47. Yang $\mathrm{H}, \mathrm{Xu} \mathrm{X}, \mathrm{Ma} \mathrm{D}$, Zhang K, Lai R. A phospholipase A1 platelet activator from the wasp venom of Vespa magnifica (Smith). Toxicon. (2008) 51:28996. doi: 10.1016/j.toxicon.2007.10.003

48. King TP, Jim SY, Wittkowski KM. Inflammatory role of two venom components of yellow jackets (Vespula vulgaris): a mast cell degranulating peptide mastoparan and phospholipase A1. Int Arch Allergy Immunol. (2003) 131:25-32. doi: 10.1159/000070431

49. Piek T. Neurotoxic kinins from wasp and ant venoms. Toxicon. (1991) 29:139-49. doi: 10.1016/0041-0101(91)90098-C

50. Choi SI, Hwang SW. Depolarizing effectors of bradykinin signaling in nociceptor excitation in pain perception. Biomol Ther. (2018) 26:25567. doi: 10.4062/biomolther.2017.127

51. Legat FJ. Itch in atopic dermatitis - what is new? Front Med. (2021) 8:644760. doi: 10.3389/fmed.2021.644760

52. Legat FJ, Griesbacher T, Lembeck F. Mediation by bradykinin of rat paw oedema induced by collagenase from Clostridium histolyticum. $\mathrm{Br} \mathrm{J}$ Pharmacol. (1994) 112:453-60. doi: 10.1111/j.1476-5381.1994.tb13094.x 
53. Hosogi M, Schmelz M, Miyachi Y, Ikoma A. Bradykinin is a potent pruritogen in atopic dermatitis: a switch from pain to itch. Pain. (2006) 126:1623. doi: 10.1016/j.pain.2006.06.003

54. Touchard A, Aili SR, Fox EG, Escoubas P, Orivel J, Nicholson GM, et al. The biochemical toxin arsenal from ant venoms. Toxins. (2016) 8:30. doi: 10.3390/toxins8010030

55. Foroutan A, Haddadi NS, Ostadhadi S, Sistany N, Dehpour AR. Chloroquineinduced scratching is mediated by NO/cGMP pathway in mice. Pharmacol Biochem Behav. (2015) 134:79-84. doi: 10.1016/j.pbb.2015.04.016

56. Walsh CM, Hill RZ, Schwendinger-Schreck J, Deguine J, Brock EC, Kucirek $\mathrm{N}$, et al. Neutrophils promote CXCR3-dependent itch in the development of atopic dermatitis. Elife. (2019) 8:e48448. doi: 10.7554/eLife.48448.sa2

57. Zamith-Miranda D, Fox EGP, Monteiro AP, Gama D, Poublan LE, de Araujo AF, et al. The allergic response mediated by fire ant venom proteins. Sci Rep. (2018) 8:14427. doi: 10.1038/s41598-018-32327-z

58. Rüdrich U, Gehring M, Papakonstantinou E, Illerhaus A, Engmann J, Kapp A, et al. Eosinophils are a major source of interleukin-31 in bullous pemphigoid. Acta Derm Venereol. (2018) 98:766-71. doi: 10.2340/00015555-2951

59. Rao KN, Brown MA. Mast cells. Ann N Y Acad Sci. (2008) 1143:83104. doi: 10.1196/annals.1443.023

60. Pasparakis M, Haase I, Nestle FO. Mechanisms regulating skin immunity and inflammation. Nat Rev Immunol. (2014) 14:289-301. doi: 10.1038/nri3646

61. Luo J, Feng J, Liu S, Walters ET, Hu H. Molecular and cellular mechanisms that initiate pain and itch. Cell Mol Life Sci. (2015) 72:320123. doi: 10.1007/s00018-015-1904-4

62. Indra AK. Epidermal TSLP: a trigger factor for pathogenesis of atopic dermatitis. Expert Rev Proteom. (2013) 10:30911. doi: 10.1586/14789450.2013.814881

63. Campion M, Smith L, Gatault S, Métais C, Buddenkotte J, Steinhoff M. Interleukin-4 and interleukin-13 evoke scratching behaviour in mice. Exp Dermatol. (2019) 28:1501-4. doi: 10.1111/exd.14034

64. Huang J, Li G, Xiang J, Yin D, Chi R. Immunohistochemical study of serotonin in lesions of chronic eczema. Int J Dermatol. (2004) 43:7236. doi: 10.1111/j.1365-4632.2004.02196.x

65. Morita T, McClain Shannan P, Batia Lyn M, Pellegrino M, Wilson Sarah R, Kienzler Michael A, et al. HTR7 mediates serotonergic acute and chronic itch. Neuron. (2015) 87:124-38. doi: 10.1016/j.neuron.2015. 05.044

66. Calixto MC, Trichês KM, Calixto JB. Analysis of the inflammatory response in the rat paw caused by the venom of Apis melifera bee. Inflamm Res. (2003) 52:132-9. doi: 10.1007/s000110300026

67. Prado M, Solano-Trejos G, Lomonte B. Acute physiopathological effects of honeybee (Apis mellifera) envenoming by subcutaneous route in a mouse model. Toxicon. (2010) 56:1007-17. doi: 10.1016/j.toxicon.2010. 07.005
68. Mollanazar NK, Smith PK, Yosipovitch G. Mediators of chronic pruritus in atopic dermatitis: getting the itch out? Clin Rev Allergy Immunol. (2016) 51:263-92. doi: 10.1007/s12016-015-8488-5

69. Miao X, Huang Y, Liu TT, Guo R, Wang B, Wang XL, et al. TNF- $\alpha /$ TNFR1 signaling is required for the full expression of acute and chronic itch in mice via peripheral and central mechanisms. Neurosci Bull. (2018) 34:4253. doi: 10.1007/s12264-017-0124-3

70. Konda D, Chandrashekar L, Rajappa M, Kattimani S, Thappa DM, Ananthanarayanan PH. Serotonin and interleukin-6: association with pruritus severity, sleep quality and depression severity in Prurigo Nodularis. Asian J Psychiatr. (2015) 17:24-8. doi: 10.1016/j.ajp.2015. 07.010

71. Sturm GJ, Kranzelbinder B, Schuster C, Sturm EM, Bokanovic D, Vollmann J, et al. Sensitization to Hymenoptera venoms is common, but systemic sting reactions are rare. J Allergy Clin Immunol. (2014) 133:163543.e1. doi: 10.1016/j.jaci.2013.10.046

72. Sturm GJ, Schuster C, Kranzelbinder B, Wiednig M, Groselj-Strele A, Aberer W. Asymptomatic sensitization to hymenoptera venom is related to total immunoglobulin E levels. Int Arch Allergy Immunol. (2008) 148:2614. doi: 10.1159/000161586

73. Schafer T, Przybilla B. IgE antibodies to Hymenoptera venoms in the serum are common in the general population and are related to indications of atopy. Allergy. (1996) 51:372-7. doi: 10.1111/j.1398-9995.1996.tb00144.x

74. Wang F, Trier AM, Li F, Kim S, Chen Z, Chai JN, et al. A basophil-neuronal axis promotes itch. Cell. (2021) 184:422-40.e17. doi: 10.1016/j.cell.2020. 12.033

Conflict of Interest: The authors declare that the research was conducted in the absence of any commercial or financial relationships that could be construed as a potential conflict of interest.

Publisher's Note: All claims expressed in this article are solely those of the authors and do not necessarily represent those of their affiliated organizations, or those of the publisher, the editors and the reviewers. Any product that may be evaluated in this article, or claim that may be made by its manufacturer, is not guaranteed or endorsed by the publisher.

Copyright (c) 2021 Cerpes, Repelnig and Legat. This is an open-access article distributed under the terms of the Creative Commons Attribution License (CC BY). The use, distribution or reproduction in other forums is permitted, provided the original author(s) and the copyright owner(s) are credited and that the original publication in this journal is cited, in accordance with accepted academic practice. No use, distribution or reproduction is permitted which does not comply with these terms. 